\title{
Treatment of Leprosy with a Combination of Injectable Thiambutosine (CIBA i go6), Streptomycin and Isoniazid
}

\author{
E. J. SGHULZ, M.MED. (DERM), D.P.H. \\ M. L. EGNAL, M.B., B.GH., D.P.H. \\ G. DOEVENDANS, MED. DRs. ARTs. \\ Westfort Institution, Pretoria, Republic of South Africa.
}

In previous trials done at the Westfort Institution, oral thiambutosine (CIBA I906, diphenylthiourea) has been shown to be as effective as dapsone in the treatment of leprosy. (Davison, I 965). Intramuscular injections have a similar effect. (Browne, I 965). The results obtained with the use of anti-tuberculosis drugs, including streptomycin and isoniazid in leprosy are 'equivocal and on the whole, disappointing' (Cochrane and Davey, I964). As far as we know there are no previous reports of the treatment of leprosy with a combination of thiambutosine, streptomycin and isoniazid. In I 963 Dr B. A. Dormer, Advisor on Tuberculosis to the State Health Department, Republic of South Africa, found that intramuscular thiambutosine plus streptoneotizide injections (containing streptomycin sulphate and sodium methane-sulphonate of isonicotinic acid hydrazide) gave better results than any previous treatment in human and animal tuberculosis. (Dormer, I963). At his suggestion a similar form of combined treatment was tried on leprosy patients at the Westfort Institution.

\section{METHOD}

The project consisted of three groups of lepromatous patients, each group being equal, as far as possible to the other with regard to the clinical and bacteriological status and previous treatment with dapsone. Treatment was continued for one year in each group.

Patients were examined and photographed at the start of the project, and clinical and bacteriological examinations were repeated at monthly intervals.

I,esions, i.e. infiltrations, macules and plaques were graded according to severity from o to 3 in three sites each (face, trunk and limbs). The maximum lesion index possible was therefore 27 .

The Bacteriological Index was obtained from the results of scrapings taken from four sites, and graded from $\frac{1}{2}$ to 4 each, the maximum therefore being 16 .

The presence of erythema nodosum leprosum was recorded at each monthly examination.

The number of patients and the treatment received in each group was as follows:

$\begin{array}{cc}\text { Group } & \begin{array}{c}\text { Number of } \\ \text { Patients }\end{array} \\ \text { A } & \text { I } 7 \\ \text { B } & \text { I5 } \\ & \\ \text { C } & \text { I } 4\end{array}$

D OSAGE

The dose of dapsone was I oo mgm daily for six days a week.

For the first five weeks patients in group B and C received bi-weekly Streptoneotizide injections (Erba) with a total of $4 \mathrm{~g}$ streptomycin sulphate and $2.4 \mathrm{~g}$ sodium methanesulfonate of isonicotinic acid hydrazide per week. As the injections were extremely painful they were stopped and streptomycin $4 \mathrm{~g}$ weekly and isoniazid tablets $3.6 \mathrm{~g}$ weekly were given instead for the rest of the year.

Thiambutosine $2 \mathrm{~g}$ was given in a single weekly intramuscular injection in one site. (During the year's treatment two sterile abscesses occurred). 


\section{RESUL'S}

The lesion and bacteriological indices before and after treatment are presented in Table I. It can be seen that the lesions regressed in all groups with no significant difference between them. In Group A which received dapsone alone, the average fall in the bacteriological index after treatment, was greater than in the other two groups.

E.N.L. occurred in all groups during the year of treatment. It was most frequent in the group receiving dapsone alone. However, the number of patients is too small to draw any conclusions about the incidence of E.N.L. in the different groups.

TABLE I

Results After One Year of Treatment

\begin{tabular}{|c|c|c|c|c|c|}
\hline \multirow[t]{2}{*}{ Group } & \multirow[t]{2}{*}{$\begin{array}{l}\text { Number of } \\
\text { Patients }\end{array}$} & \multicolumn{2}{|c|}{$\begin{array}{c}\text { Average } \\
\text { Lesion Index }\end{array}$} & \multicolumn{2}{|c|}{$\begin{array}{c}\text { Average } \\
\text { Bacteriological } \\
\text { Index }\end{array}$} \\
\hline & & Before & After & Before & After \\
\hline A & 17 & $4 \cdot 7$ & $4 \cdot 0$ & I 5.2 & го. 6 \\
\hline B & 15 & $5 \cdot 2$ & $3 \cdot 9$ & 14.9 & 13.0 \\
\hline G & 14 & $6 . \mathrm{I}$ & $5 \cdot \mathrm{I}$ & 14.6 & I 3.5 \\
\hline
\end{tabular}

\section{SUMMARY AND CIONGLUSION}

Twenty-nine patients with lepromatous leprosy were treated with a combination of injectable thiambutosine, streptomycin and isoniazid, for one year. This treatment was not found to be more effective than dapsone alone.

\section{A CKN OWLEDGEMENT}

This paper is published with the permission of the Secretary for Health, Republic of South Africa. We are indebted to Messrs Ciba (Pty) Ltd, for supplying us with injectable thiambutosine.

\section{REF E R E N C E}

Browne, s. G., Lep. Rev. ( I 965), 36, 2 I.

COCHRANE, R. G. and DAVEY, T. F., Leprosy in Theory and Practice.

JOHN WRIGHT AND SONS LTD., Bristol, I964.

DAvison, A. R., Lep. Rev. (1965), 36, 145 .

DORMER, B. A., Personal communication. 